Original Research Paper

\title{
Pendampingan Kerja Praktik Untuk Meningkatkan Keterampilan Proses IPA Bagi Guru Guru SD Di Kota Mataram
}

\author{
I Wayan Gunada ${ }^{1 *}$, Sutrio ${ }^{1}$, Wahyudi ${ }^{1}$, Ni Nyoman Sri Putu Verawati ${ }^{1}$, Ahmad Busyairi ${ }^{1}$, Ananda \\ Fatara Suwandi ${ }^{2}$ \\ ${ }^{1}$ Program Studi Pendidikan Fisika FKIP Universitas Mataram, Mataram, Indonesia \\ ${ }^{2}$ Mahasiswa Program Studi Pendidikan Fisika FKIP Universitas Mataram, Mataram, Indonesia
}

https://doi.org/10.29303/jpmpi.v3i2.1137

Sitasi: Gunada, I. W., Sutrio., Wahyudi., Verawati, N. N. S. P., Busyairi, A \& Suwandi, A. F. (2021). Pendampingan Kerja Praktik Untuk Meningkatkan Keterampilan Proses IPA Bagi Guru Guru SD Di Kota Mataram. Jurnal Pengabdian Magister Pendidikan IPA 4(4)

\section{Article history}

Received: 02 Oktober 2021

Revised: 20 Oktober 2021

Accepted: 07 November 2021

*Corresponding Author: I

Wayan Gunada, Program

Studi Pendidikan Fisika

FKIP Universitas Mataram, Mataram, Indonesia

Email:

wayan_gunada@unram.ac.id

\begin{abstract}
In elementary schools (SD), KIT IPA equipment is used to practice teaching and learning activities that teachers have not used to their full potential. Kit of knowledge and management abilities Teachers require IPA SD to advance their school. The management of KIT IPA is less effective and has become a major issue for elementary schools (SD) Group IV Cakranegara. The goal of this community service activity is to teach people about the names of the tools in some SD IPA KIT IPA SD, how to use them, and how to use KIT IPA SD in the learning process. This devotional activity employs lecture methods, simulations, and practical work. This activity was held in SD Negeri 1 Cakranegara, with as many as 28 teachers participating. The activities' outcomes demonstrated that participants gained knowledge and skills on how to teach IPA by utilizing KIT IPA tools for practical work activities. Based on observations from practical work, the average value of process skills of teachers was 70 and classified quite well. The positive response from teachers in mentoring activities indicates that this activity is running smoothly, and it is expected that there will be additional training for other KIT equipment as a result of this activity.
\end{abstract}

Keywords: KIT IPA SD, Process Skills

\section{Pendahuluan}

Undang-undang No 14 tahun 2005 tentang guru dan dosen menyatakan dengan tegas bahwa Guru wajib memiliki kualifikasi akademik, kompetensi, sertifikat pendidik, dan sebagainya. Dengan demikian, guru dituntut menguasai berbagai kemampuan. Salah satu kemampuan yang harus dikuasai adalah mengembangkan diri secara profesional. Standar kompetensi yang harus dimiliki guru mencakup empat jenis kompetensi yaitu: kompetensi pedagogik, kepribadian, profesional, dan sosial.

Kompetensi pedagogik adalah kemampuan mengelola pembelajaran yang meliputi pemahaman peserta didik, perancangan dan pelaksanaan pembelajaran, evaluasi hasil belajar, dan pengembangan peserta didik untuk mengaktualisasikan berbagai potensi yang dimilikinya. Kompetensi kepribadian adalah kemampuan kepribadian yang mantap, stabil, dewasa, arif dan berwibawa, menjadi teladan peserta didik, dan berakhlak mulia. Kompetensi profesional adalah kemampuan penguasaan materi 
pembelajaran secara luas dan mendalam, yang memungkinkannya membimbing peserta didik memenuhi standar kompetensi yang ditetapkan dalam standar nasional pendidikan. Kompetensi sosial adalah kemampuan pendidik sebagai bagian dari masyarakat untuk berkomunikasi dan bergaul secara efektif dengan peserta didik, sesama pendidik, tenaga kependidikan, orang tua/wali peserta didik, dan masyarakat sekitar (Dirjen Dikti, 2005). Terkait dengan kompetensi pedagogik, seorang guru harus merancang atau menggunakan KIT IPA sebagai sarana praktik dalam proses pembelajaran.

Hakikat dari ilmu sains adalah proses penemuan (inquiry). Idealnya, setiap topik dari pembelajaran IPA sebaiknya diajarkan melalui peragaan kepada peserta didik, dalam bentuk percobaan atau demonstrasi yang dilakukan di laboratorium atau di ruang kelas. Sains atau ilmu pengetahuan berhubungan dengan cara bagaimana mencari tahu tentang alam secara sistematis (Muthmainnah dkk., 2016) Pada mata pelajaran IPA, konsep dan sub-konsep dipelajari melalui penelitian sederhana, percobaan dan sejumlah kegiatan praktis dengan fokus pada pengembangan keterampilan proses. IPA bukan hanya penguasaan kumpulan pengetahuan yang berupa fakta-fakta, konsep-konsep, atau prinsip-prinsip saja tetapi juga merupakan suatu proses penemuan dengan tujuan pembentukan keterampilan ilmiah serta sikap ilmiah (Satria \& Sari, 2018). Tingkat penguasaan dan keterampilan proses sains merupakan dasar keterampilan akademik, di samping sebagai "basic learning tools" yang merupakan ketrampilan untuk membentuk landasan pada setiap individu dalam mengembangkan diri secara lebih lanjut (Faqih,2015)

Mengajarkan mata pelajaran tidak cukup hanya dengan menggunakan kapur dan papan tulis saja. Pembelajaran siswa secara umum dituntut untuk mengikuti perkembangan jaman dan teknologi, maka proses belajar pun dibutuhkan suatu teknologi baik itu secara teknik, strategi, taktik, metode, model pembelajaran dan yang lainnya untuk mengikuti berlangsungnya perkembangan tersebut (Marliani, 2015). Sekarang ini tuntutan pembelajaran tidak hanya memberikan sejumlah fakta, yang makin lama jumlahnya makin banyak yang harus dihafalkan oleh peserta didik, tetapi peserta didik juga harus dapat menjelaskan mengapa fakta itu ada, bagaimana fakta itu terjadi, dan di mana fakta itu dapat terjadi. Agar dapat memahami seluruh tuntutan pembelajaran itu, tidak cukup dengan hanya memberikan ceramah kepada peserta didik.

Agar dalam proses pembelajaran sesuai dengan tujuan pembelajaran IPA, maka diperlukan suatu sarana peralatan laboratorium IPA untuk melakukan percobaan (Rahayu, dkk., 2020 ) Pemerintah telah memberikan peralatan laboratorium berupa KIT IPA SD. KIT IPA SD adalah peralatan laboratorium/praktikum yang dikemas dalam bentuk modular KIT. Modular KIT dengan sistim pengepakan yang lebih rapi dan praktis akan membantu sekolah memiliki peralatan yang baku, bersifat serba guna dan berdaya guna tinggi serta tahan lama. Secara keseluruhan jenisjenis percobaan yang dapat dilaksanakan dengan percobaan KIT ini telah disesuaikan dengan ketentuan di dalam Kurikulum yang berlaku.

Permasalahan yang sering ditemui dalam pembelajaran di laboratorium yaitu pengelolaan laboratorium yang meliputi proses pengadaan, proses penggunaan, dan proses pemeliharaan (Dewi dkk, 2019). Laboratorium IPA merupakan salah satu fasilitas sekolah tempat guru dan peserta didik melakukan kegiatan pembelajaran IPA melalui praktikum (Pane \& Silabang, 2021). Berdasarkan hasil wawancara dan observasi disekolah ditemukan beberapa permasalahan diantaranya dalam proses pembelajaran IPA terutama pada saat kerja praktik, guru jarang melakukan pembelajaran dengan menggunakan metode eksperimen. Akar dari permasalahannya adalah para guru IPA takut melakukan percobaan yang berhubungan dengan listrik, guru-guru juga jarang melakukan percobaan dengan menggunakan KIT, alat bantu pengajaran sebenarnya memegang peranan yang sangat penting, khususnya untuk pengajaran IPA (Wiyatmo dkk, 2018).

Selain itu alat peraga dan KIT IPA lebih banyak tersimpan rapi di ruangan guru atau di ruang perpustakaan. Pembelajaran IPA yang dilakukan guru dengan cara mengingat fakta fakta tidak akan banyak membuat peserta didik tertarik dan senang dalam belajar. Pembelajaran seperti itu bias menyebabkan banyak siswa kurang memahami pelajaran IPA yang diberikan oleh guru. Hal lain seperti yang diungkapkan Adji \& Rokhiyah (2011) kendala yang ditemukan dalam penggunaan alat peraga IPA sebagai alat bantu dalam proses pembelajaran IPA di MI NW Teababan dan SDN 4 
Tebaban diantaranya guru kurang mengenal alatalat dalam KIT IPA SD, dan guru belum terlatih mencoba menggunakan alat KIT IPA.

Hartati (2010) mengungkapkan bahwa untuk penunjang terselenggaranya proses pembelajaran yang menyenangkan perlu disediakan alat peraga yang memadai. Alat peraga dapat memperjelas bahan pengajaran yang diberikan guru kepada siswa sehingga siswa lebih mudah memahami materi atau soal yang disajikan guru (Lestari, 2006). Alat peraga juga menarik perhatian siswa dan dapat menumbuhkan minat untuk mengikuti pembelajaran IPA (Prasetyarini dkk., 2013).

Pemanfaatan alat peraga merupakan bagian yang harus mendapat perhatian pihak sekolah dalam setiap kegiatan pembelajaran. Banyak sekolah yang memiliki alat peraga pendidikan seperti KIT IPA yang telah dikemas dengan praktis namun belum digunakan secara optimal. Pelatihan ini ditujukan bagi para guru-guru IPA SD untuk mempelajari tata cara penggunaan, untuk kerja praktik alat peraga agar penggunaan alat peraga menjadi lebih efektif, kreatif, dan efisien.

\section{Metode}

Metode yang digunakan dalam kegiatan pendampingan kerja praktik ini meliputi: metode observasi, ceramah, simulasi dan kerja praktik. Tahapan kegiatan pengabdian ini, dilakukan dalam dua tahap yaitu :

\section{a. Tahap Pertama}

Tahap pertama dilakukan kegiatan audensi dan observasi di SD Negeri 1 Cakranegara yang digunakan sebagai pusat tempat kegiatan. Pada tahap ini, kegiatan yang dilakukan observasi tempat kegiatan dan koordinasi dengan ketua gugus untuk mempertimbangkan luas ruangan dan jumlah peserta sehingga memungkinkan pelaksanaaan kegiatan yang tidak menyalahi aturan pertemuan tatap muka di masa pandemic covid 19. Pada tahap ini, juga dilakukan pengecekan alat KIT IPA yang digunakan pada saat puncak pertemuan dengan para guru.

\section{b. Tahap Kedua}

Pada tahap kedua sebagai puncak kegiatan dibagi dalam dua sesi yaitu: 1) Sesi pertama dilakukan kegiatan penyuluhan tentang pengelolaan alat-alat KIT IPA yang berisi tentang bagaimana perencanaan laboratorium, penanganan dan penataan alat, pengadministrasian dan pengamanan alat dengan menggunakan metode ceramah dan diskusi bersama, 2) Sesi kedua dilaksanakan dengan menggunakan kegiatan simulasi dan kerja praktik yaitu berupa praktikum merakit secara langsung dengan didamping oleh semua tim pengabdian. Serta memberikan pelatihan langsung tentang keterampilan proses dalam pembelajaran IPA SD. Keterampilan proses guru diamati dengan lembar observasi dan dinilai oleh semua tim pengabdian pada masyarakat.

\section{Hasil dan Pembahasan}

Kegiatan pendampingan kerja praktik menggunaan Kit IPA SD ini diikuti oleh 38 peserta yang berasal dari guru-guru SD gugus IV Cakranegara Kota Mataram Nusa Tenggara Barat. Kegiatan pelatihan ini dilaksanakan di SD Negeri 1 Cakranegara yang beralamatkan di Jalan Elang No. 18 Cakranegara. Bentuk kegiatan meliputi ceramah, diskusi-informasi, dan pendampingan kerja praktik menggunakan KIT IPA SD. Kegiatan lapangan kerja praktik yang dilakukan selengkapnya dapat dilihat pada Tabel 1 .

Tabel 1. Kegiatan Pelaksanaan Kerja Praktik

\begin{tabular}{|c|c|c|}
\hline No & Hari/Tanggal & Kegiatan \\
\hline 1 & $\begin{array}{l}\text { Jumat, } 17 \\
\text { September } \\
2021\end{array}$ & 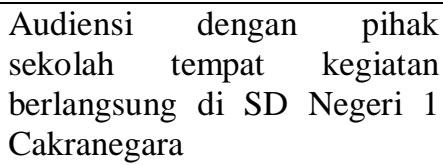 \\
\hline 2 & $\begin{array}{l}\text { Jumat, } 24 \\
\text { September } \\
2021\end{array}$ & $\begin{array}{l}\text { Persiapan materi dan } \\
\text { menyeting Kit IPA SD yang } \\
\text { akan digunakan untuk kerja } \\
\text { praktik }\end{array}$ \\
\hline 3 & $\begin{array}{l}\text { Sabtu, } 25 \\
\text { September } \\
2021\end{array}$ & $\begin{array}{l}\text { Pelaksanaan pendampingan } \\
\text { kerja praktik dengan } \\
\text { menggunakan Kit IPA SD }\end{array}$ \\
\hline
\end{tabular}

Kegiatan pengabdian secara formal telah dilakukan selama 3 hari mulai dari audensi ke sekolah, mencoba dan mengeset KIT IPA SD, serta pelaksanaan pendampingan. Pendampingan yang dilaksanakan kepada kepala sekolah dan guru. Kepada kepala sekolah dan guru diberikan wawasan betapa pentingnya pengelolaan KIT IPA SD, sehingga KIT tersebut tidak hanya menjadi pajangan di ruang kelas atau di perpustakaan. KIT 
yang tidak dipergunakan dalam jangka waktu yang lama akan berdampak pada KIT tersebut misalnya mengalami kerusakan, mengkarat, pecah, baterai mati atau kabelnya rusak. Efektif dan optimalnya pengabdian ini karena telah dilakukan pembagian tugas dalam tim, sehingga pendampingan yang dilakukan dapat berjalan secara optimal. Rincian personal tim dan pembagian tugasnya dapat dilihat pada Tabel 2.

Tabel 2. Pembagian Tugas Tim Pengabdian

\begin{tabular}{|c|c|c|}
\hline No & Nama & Tugas dalam Pengabdian \\
\hline 1 & $\begin{array}{l}\text { I Wayan } \\
\text { Gunada, } \\
\text { S.Si.,M.Pd }\end{array}$ & $\begin{array}{l}\text { Mengkoordinir tim dalam } \\
\text { kegiatan dan memberikan } \\
\text { materi dasar tentang KIT } \\
\text { IPA }\end{array}$ \\
\hline 2. & Drs Sutrio, M.Si & $\begin{array}{ll}\text { Melatih } & \text { Percobaan } \\
\text { Periskop } & \end{array}$ \\
\hline 3 & $\begin{array}{l}\text { Wahyudi,S.Si., } \\
\text { M.Si }\end{array}$ & $\begin{array}{l}\text { Melatih Percobaan } 32 \\
\text { Bayangan Pada Cermin } \\
\text { Datar dan Pembentukan } \\
\text { Bayangan Pada } 2 \text { Cermin }\end{array}$ \\
\hline 4 & $\begin{array}{l}\text { Ni Nyoman Sri } \\
\text { Putu } \\
\text { Verawati,M.Pd }\end{array}$ & $\begin{array}{l}\text { Melatih Percobaan } \\
\text { Buzzer }\end{array}$ \\
\hline 5 & $\begin{array}{l}\text { Ahmad } \\
\text { Busyairi, } \\
\text { S.Pd.,M.Pd }\end{array}$ & $\begin{array}{l}\text { Melatih Percobaan } \\
\text { Konduktor dan Isolator }\end{array}$ \\
\hline 6 & $\begin{array}{l}\text { Ananda Fatara } \\
\text { (Mahasiswa } \\
\text { yang dilibatkan) }\end{array}$ & $\begin{array}{rr}\text { Instrumen } \\
\text { dan } \begin{array}{r}\text { Lembar } \\
\text { Ketrampilan }\end{array}\end{array}$ \\
\hline
\end{tabular}

Berdasarkan panduan buku KIT IPA SD jumlah percobaan yang ada pada satu kotak KIT berjumlah 36 percobaan, hanya saja pada saat pendampingan telah dipilih materi-materi percobaan yang dapat meningkatkan ketrampilan proses pembelajaran IPA diantaranya: percobaan pencampuran periskop, percobaan pada cermin datar dan pembentukan bayangan pada dua cermin datar, percobaan konduktor dan isolator, serta percobaan buzzer.

Materi pelatihan menggunakan Kit IPA SD. Kegiatan penyajian dan diskusi yang telah dilaksanakan bertujuan untuk memberikan pemahaman dan wawasan tentang bagaimana memberikan pengetahuan tentang nama alatalat yang ada pada beberapa Kit serta kegunaan alat-alat yang ada di dalam Kit IPA SD. Penyajian materi dan diskusi menyasar tujuan dari kegiatan ini. Di awal kegiatan, sebelum pemberian materi dan pendampingan kerja praktik peserta diberikan kuisioner dan hasilnya dapat disajikan pada Tabel 3.

Tabel 3. Hasil Data Awal

\begin{tabular}{|c|c|c|c|}
\hline \multirow{2}{*}{$\begin{array}{l}\text { No } \\
1\end{array}$} & \multirow{2}{*}{\begin{tabular}{l}
\multicolumn{1}{c}{ Pertanyaan } \\
Tersediakah \\
laboratorium IPA di \\
sekolah anda?
\end{tabular}} & \multicolumn{2}{|c|}{$\begin{array}{c}\text { Prosentasi Jawaban } \\
\text { Peserta }\end{array}$} \\
\hline & & $\begin{array}{l}\text { Ada } \\
(0 \%)\end{array}$ & $\begin{array}{l}\text { Tidak } \\
\text { Ada } \\
(100 \%)\end{array}$ \\
\hline 2. & $\begin{array}{l}\text { Sebagai guru kelas/IPA, } \\
\text { apakah sebelumnya } \\
\text { anda pernah menerima } \\
\text { penjelasan atau } \\
\text { pelatihan pengelolahan } \\
\text { laboratorium? }\end{array}$ & $\begin{array}{l}\text { Pernah } \\
(17,86 \%)\end{array}$ & $\begin{array}{l}\text { Tidak } \\
\text { Pernah } \\
(82.21 \%)\end{array}$ \\
\hline 3 & $\begin{array}{l}\text { Sebagai guru, } \\
\text { pernahkah anda } \\
\text { menggunakan salah satu } \\
\text { bagian KIT sebagai } \\
\text { sarana pembelajaran }\end{array}$ & $\begin{array}{l}\text { Pernah } \\
(35.71 \%)\end{array}$ & $\begin{array}{l}\text { Tidak } \\
\text { Pernah } \\
(64,29 \%)\end{array}$ \\
\hline 4 & $\begin{array}{l}\text { Tersediakah KIT IPA } \\
\text { disekolah? }\end{array}$ & $\begin{array}{l}\text { Tersedia } \\
(100 \%)\end{array}$ & $\begin{array}{l}\text { Tidak } \\
\text { Tersedia } \\
(0 \%)\end{array}$ \\
\hline 5 & $\begin{array}{l}\text { Pernahkah anda } \\
\text { menggunakan KIT IPA } \\
\text { dalam pembelajaran? }\end{array}$ & $\begin{array}{l}\text { Pernah } \\
(17,86 \%)\end{array}$ & $\begin{array}{l}\text { Tidak } \\
\text { Pernah } \\
(82.21 \%)\end{array}$ \\
\hline 6 & $\begin{array}{l}\text { Pelukah anda mengikuti } \\
\text { kegiatan } \\
\text { pelatihan/pendampingan } \\
\text { Penggunaan KIT IPA } \\
\text { SD }\end{array}$ & $\begin{array}{l}\text { Perlu } \\
(96,43 \%)\end{array}$ & $\begin{array}{l}\text { Tidak } \\
\text { Perlu } \\
(3.57 \%)\end{array}$ \\
\hline
\end{tabular}

Hasil data awal yang diperoleh dari guru-guru SD gugus IV Cakranegara menunjukkan bahwa ketersediaan laboratorium IPA di SD belum ada. Pihak sekolah atau pemerintah perlu menyediakan adanya laboratorium IPA untuk meningkat kreatifitas guru dalam menyampaikan materi dan untuk meningkatkan ketrampilan proses IPA. Selain itu, pentingnya laboratorium SD digunakan untuk mengenalkan siswa sejak dini tentang alat - alat sains dasar sehingga siswa setelah 
melanjutkan kejenjang sekolah yang lebih tinggi sudah memiliki bekal pengetahuan dasar yang kuat. Pengadaan laboratorium di SD perlu diperhatikan untuk kemajuan pendidikan di masa depan. Karena pendidikan dizaman modern sekarang sudah menggunakan alat atau media yang lebih modern.

Data pada tabel di atas menunjukkan bahwa $17.86 \%$ guru yang sudah pernah menerima penjelasan dan $82.21 \%$ yang belum pernah menerima penjelasan atau pelatihan pengelolahan laboratorium termasuk mengunakan KIT IPA SD. Artinya pihak sekolah harus memberikan pelatihan penggunaan KIT IPA dan pengelolaan laboratorium kepada guru IPA SD. Sehingga pendampingan kerja praktik penggunaan KIT IPA ini sangat perlu dilakukan. Pelatihan kerja praktik dan pengetahuan pengelolaan laboratorium perlu dimiliki oleh seorang guru sebagai tuntutan kemampuan profesionalisme. Karena tuntutan pendidikan abad 21 dimana kreatifitas diperlukan untuk bersaing. Perbandingan antara guru yang pernah menggunakan dan belum menggunakan KIT sangat besar dimana, guru yang pernah menggunakan KIT dipresentasekan sebesar $35,71 \%$ sedangkan guru yang belum menggunakan KIT sebesar $64,29 \%$. Dari perbandingan tersebut dapat dilihat juga bahwa rendahnya kemampuan guru dalam mengaplikasikan KIT IPA dalam proses pembelajaran. Artinya guru yang belum menggunakan KIT tentu tidak merasakan manfaat dari pembelajaran menggunakan KIT, termasuk didalamnya tentang keterampilan proses sains.

Persentase ketersediaan KIT IPA di sekolah $100 \%$. Artinya di sekolah-sekolah SD gugus IV tersebut tersedia KIT IPA untuk menunjang pembelajaran IPA di SD. Hanya saja belum dioptimalkan secara maksimal. Ketersediaan KIT IPA SD memudahkan guru untuk menjelaskan konsep materi yang diajarkan dan siswa jadi lebih mudah untuk memahami materi yang disampaikan oleh guru. Sedangkan persentase guru pernah mengajar menggunakan KIT IPA $17.86 \%$ dan tidak mengajar menggunakan KIT IPA $82.21 \%$. Artinya Sebagian besar guru IPA tidak menggunakan KIT IPA dalam proses pembelajaran. Berdasarkan data yang diperoleh dari para guru mereka perlu mengikuti kegiatan pelatihan/pendampingan penggunaan KIT IPA SD sebesar $96,43 \%$. Artinya bahwa berdasarkan data awal yang diperoleh pendampingan praktik kerja menggunakan KIT IPA SD sangat penting untuk mengoptimalkan penggunaaan KIT disekolah.

Proses kegiatan pendampingan kerja praktik dilakukan secara luring di SD Negeri 1 Cakranegara dan telah sesuai serta mematuhi protokol Kesehatan.

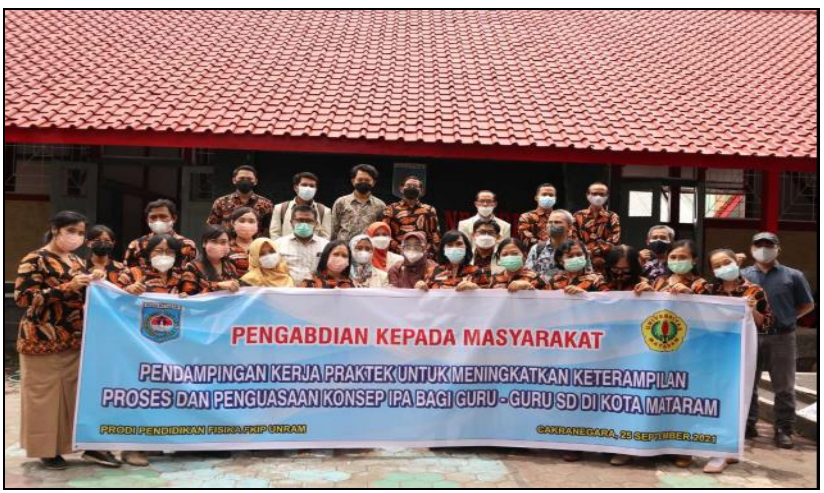

Gambar 1. Kegiatan Foto Bersama di SD Negeri 1 Cakranegara

Kegiatan Pengabdian kepada masyarakat untuk para guru-guru SD gugus IV Cakranegara dilakukan dengan langkah-langkah sebagai berikut:

1. Memberikan ceramah tentang cara-cara bagaimana mengelola KIT IPA SD dan mengenalkan nama-nama alat yang terdapat dalam KIT IPA.

2. Demonstrasikan bagaimana cara penggunaan alat-alat KIT IPA SD dan mendemontrasikan salah satu percobaan yaitu percobaan tentang energi..

3. Kegiatan berikutnya dilakukan pembagian kelompok peserta yang dibagi menjadi 4 kelompok untuk melaksanakan kerja praktik mencoba menggunakan alat-alat KIT IPA SD dan masing-masing kelompok mencoba percobaan yang telah ditentukan serta didampingi oleh tim pengabdian.

4. Kegiatan selanjutnya dilakukan dengan mencoba ulang menggunakan percobaan alat alat KIT IPA SD dengan mengikuti langkahlangkat pada buku panduan. Pada tahap ini juga dilakukan observasi ketrampilan proses IPA guru yang dilakukan oleh tim pengabdian serta dibantu oleh mahasiswa yang dilibatkan dalam pengabdian. Penilaian ketrampilan proses yang dilakukan untuk mengetahui sejauhmana 
dampat dari kegiatan pelatihan yang telah dilakukan. Ketrampilan proses sain yang diukur meliputi kemampuan: pengamatan, pengukuran, menyimpulkan, meramalkan, menggolongkan dan mengkomunikasikan.

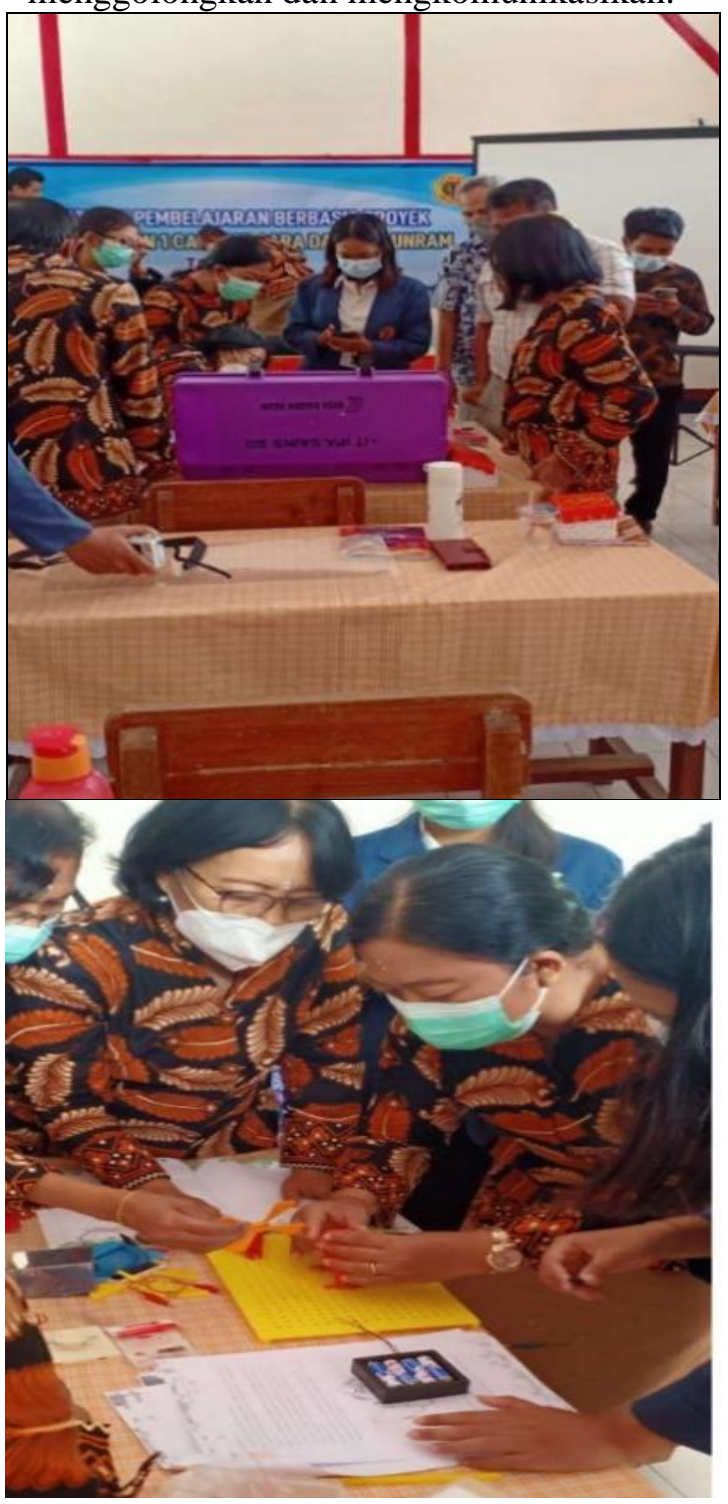

Gambar 2a dan Gambar 2b

Gambar 2a. Pendampingan Kerja Praktik di Bantu oleh Mahasiswa

Gambar 2b. Para Guru Peserta Mencoba Salah Satu Percobaan KIT IPA SD

Data hasil ketrampilan proses guru dinilai oleh tim pengabdian pada saat peserta (guru) merakit percobaan yang telah ditentukan pada KIT IPA SD dengan tim dalam kelompoknya. Penilaian dilakukan dengan memberikan skor pada masingmasing kelompok sesuai dengan indikator ketrampilan proses IPA. Data hasil skor rata-rata ketrampilan proses IPA peserta dapat dilihat pada Tabel 4.

Tabel 4. Skor Rata-Rata Ketrampilan Proses IPA

\begin{tabular}{llc}
\hline No & \multicolumn{1}{c}{ Indikator } & $\begin{array}{c}\text { Rata Rata } \\
\text { Skor Keterampilan } \\
\text { Proses IPA Guru }\end{array}$ \\
\hline 1 & Pengamatan & 70 \\
2. & Pengukuran & 70 \\
3 & Menyimpulkan & 70 \\
4 & Meramalkan & 60 \\
5 & Menggolongkan & 70 \\
6 & Mengkomunikasikan & 80 \\
\hline
\end{tabular}

Bersadarkan data yang diperoleh indikator pengamatan, pengukuran, menyimpulkan, dan menggolongkan memperoleh skor rata-rata 70, indikator meramalkan atau memperkirakan memperoleh skor rata-rata 60, sedangkan kemampuan mengkomunikasikan memperoleh skor rata-rata 80. Artinya pada indikator meramalkan atau memperkirakan suatu hal yang akan terjadi atau sesuatu hal yang terjadi setelah peralatan KIT dirangkai masih kurang dan hal ini hamper sama dengan membuat dugaan atau hipotesis. Sedangkan kemampuan mengkomunikasikan hasil percobaan memperoleh skor rata-rata 80 , hal ini menunjukan bahwa ketrampilan proses IPA terutama pada indikator mengkomunikasikan para peserta sudah mampu menyampaikan hasil percobaan yang diperolehnya. Pada indikator ini jika dibandingkan dengan indikator yang lainnya bahwa guru gugus IV Cakranegara mempunyai kemampuan komunikasi yangg baik dalam menyampaikan hasil kegitana praktik.

Pengetahuan para guru - guru gugus IV Cakranegara penggunaan KIT IPA SD bantuan dari pemerintah sangatlah beragam. Keberagaman pengetahuan dan keterampilan guru-guru disebabkan karena ada beberapa guru bahkan sebagian besar yang mengikuti kegiatan pelatihan kualifikasi pendidikannya bukan dari pendidikan IPA ataupun pada saat menempuh S1 PGSD materi Pendidikan sains terutama dalam kegiatan praktikum belum diperolehnya. Merupakan suatu tantangan yang besar bagi tim pelatihan untuk memberikan pengetahuan, pemahaman dan keterampilan bagaimana menggunakan alat-alat KIT IPA SD tersebut. 
Selain pengetahuan tentang penggunaan alat-alat laboratorium yang telah dikemas dalam bentuk KIT IPA SD, para peserta pelatihan juga belum memahami bagaiman cara merawat alat-alat KIT IPA SD agar tetap terjaga kondisinya. Pada awal kegiatan pelatihan ini terlihat masih banyak peserta yang sama sekali tidak mengenal namanama alat yang ada di dalam KIT IPA beserta kegunaannya. Selain itu, peserta tidak mau menggunakan KIT IPA dikarenakan takut peralatannya menjadi rusak. Para tim pelatihan memberikan pengarahan tentang bagaimana, memberikan pengenalan alat-alat yang ada dalam KIT IPA SD beserta kegunaannya juga memberikan demonstrasi bagaimana merangkai alat-alat tersebut dalam beberapa percobaan. Para peserta terlihat antusias dalam merangkai alat-alat serta terlihat senang dapat pengalaman baru. Faktor Pendorong kegiatan ini adalah guru-guru gugus IV Cakranegara diharapkan dapat memanfaatkan alat-alat KIT IPA sebagai media pembelajaran IPA. Kegiatan ini bagus dilaksanakan untuk memperbaiki proses pembelajaran mengingat hakikat IPA adalah produk, sikap dan proses. Selain memperbaiki proses pembelajaran pendampingan kerja praktik ini diharapkan dapat meningkatkan ketrampilan proses dan penguasaan konsep IPA. Sedangkan faktor penghambat pada proses pendampingan ini, disebabkan situasi pandemic covid 19, sehingga memerlukan waktu yang tepat dan koordinasi dengan pihak ketua gugus IV. Selain itu memerlukan ruangan yang cukup luas dalam tahap implementasi pendampingan di sekolah, agar tidak melanggar protokol Kesehatan. Hal lain yang menjadi faktor penghambat kegiatan ini adalah keinginan guru-guru dalam mencoba penggunaan alat-alat praktikum KIT IPA tidak semua materi percobaan tidak bisa dilaksanakan karena terbatasnya waktu dan biaya untuk pengabdian. Para peserta berharap bisa dilakukan pelatihan pada materi percobaan KIT IPA SD yang lainnya.

KIT IPA sangatlah penting untuk membantu proses pembelajaran terutama dalam meningkatkan ketrampilan proses IPA, seperti yang diungkapkan Faqih,(2015) mengungkapkan bahwa menempatkan KIT IPA sebagai alat peraga untuk memantapkan pemahaman konsep IPA serta sebagai jembatan penghubung antara konsep teori IPA dengan aplikasi dalam kehidupan nyata (77,65\% responden setuju), sehinggan keberadaan
KIT IPA sangat dibutuhkan $(77,72 \%$ responden setuju).

\section{Kesimpulan}

Kegiatan pendampingan ini dapat menambah wawasan dan pengetahuan guru-guru SD Gugus IV Cakranegara dalam mengunakan alatalat yang ada di dalam KIT IPA SD dan melalui pendampingan pelatihan ini guru lebih senang mengajar IPA dengan memanfaatkan KIT IPA SD untuk meningkatkan ketrampilan proses dan meningkatkan pemahaman konsep IPA. Penggunakan alat-alat KIT IPA SD untuk kegiatan kerja praktik bagi guru-guru IPA sebaiknya dilakukan dengan tahapan sebagai berikut : 1) mempelajari buku pedoman yang ada dalam KIT IPA SD, 2) mempelajari katalog alat yang terdapat dalam KIT IPA, dan 3) mencoba merancang sendiri tiap percobaan yang ada dalam buku pedoman.

\section{Ucapan Terima Kasih}

Penulis mengucapkan terima kasih kepada FKIP Universitas Mataram, atas dana pengabdian PNBP tahun 2021.

\section{Daftar Pustaka}

Adji, S. S., \& Rokhiyah, I. 2011. Kesenjangan Antara Persepsi Dan Harapan Mahasiswa Pada Kegiatan Tutorial Tatap Muka Mata Kuliah Praktikum Ipa Sd. Jurnal Pendidikan Terbuka Dan Jarak Jauh, (12),2, 100-108, http://jurnal.ut.ac.id/index.php/jptjj/article/ view/432.

Dewi, dkk. 2019. Analisis Pengelolaan Alat dan Bahan Praktikum pada Laboratorium Kimia Di Sma Negeri 1 Tampaksiring. Jurnal Pendidikan Kimia Undiksha, (3),1, 37-42,:

https://ejournal.undiksha.ac.id/index.php/JJ PK/article/view/21162.

Dirjen Dikti. 2005. Pedoman Umum: Pengembangan Sistem Asesmen Berbasis Kompetensi. Depdiknas: Jakarta.

Faqih, A. 2015. Optimalisasi Pemanfaatan KIT-IPA PGSD Untuk Meningkatkan Keterampilan 
Proses Keterampilan Proses Sains Pada Pelaksanaan Tutorial Praktikum IPA di SD. Widyagogik, (3), 1, 33-42,:

https://journal.trunojoyo.ac.id/widyagogik/ article/view/2645

Hartati, B. 2010. Pengembangan Alat Peraga Gaya Gesek Untuk Meningkatkan Keterampilan Berpikir Kritis Siswa SMA. Jurnal Pendidikan Fisika Indonesia, (6), 2,128132,:

https://journal.unnes.ac.id/nju/index.php/JP FI/article/view/1125

Lestari, L., P. 2006. Keefektifan Pembelajaran dengan Menggunakan Alat Peraga dan Lembar Kerja Siswa (LKS) terhadap Hasil Belajar Matematika dalam Pokok Bahasan Bangun Segiempat pada Siswa Kelas VII Semester 2 di SMP Muhammadiyah Margasari Kabupaten Tegal Tahun Pelajaran 2005/2006, http://lib.unnes.ac.id/1311/, diakses tanggal 8 Agustus 2021.

Marliani, N. 2015. Kemampuan Pemecahan Masalah Matematis Pada Mata Kuliah Persamaan Diferensial Dilihat dari Pembelajaran Konflik Kognitif Yang Terintegrasi Dengan Soft Skill. Jurnal Formatif, (5), 2, 134-144,: https://journal.lppmunindra.ac.id/index.php Formatif/article/view/333.

Muthmainnah, Aminah, Nurmona. 2016. Pelatihan Penggunaan KIT IPA Bagi Guru Sains di SD Negeri 2 Peusangan dan MIN Krueng Panjoe Kabupaten Bireuein Propinsi Aceh. Jurnal Pendidikan Dasar (JUPENDAS), (3), $\quad$ 1, 9-12,: http://jfkip.umuslim.ac.id/index.php/jupend as/article/view/132.

Mahmudah,L.2016.Pentingnya Pendekatan Keterampilan Proses Pada Pembelajaran IPA

Di Madrasah. Jurnal Elementary,(4), 1, 167-187,:

https://journal.iainkudus.ac.id/index.php/el ementary/article/view/2047.

Pane, J. \& Silaban, B. 2021.Pelatihan Penggunaan Kit Ipa Bagi Guru Dan Siswa SMPN 32 Medan. J Abdi:Jurnal Pengabdian Kepada Masyarakat, (1),3,233-238,
https://bajangjournal.com/index.php/JABDI/article/view/114.

Prasetyarini, A., Desy, S. F., \& Akhdinirwanto, W. 2013. Pemanfaatan Alat Peraga IPA untuk Peningkatan Pemahaman Konsep Fisika pada Siswa SMP Negeri 1 Bulupesantren Kebumen Tahun Pelajaran 2012/2013. Radiasi, (2), 1, 7-10, : http://jurnal.umpwr.ac.id/index.php/radiasi/ article/view/370.

Satria, E., \& Sari,S.,G. 2018. Penggunaan Alar Peraga dan KIT IPA oleh Guru Dalam Pembelajaran Di Beberapa Sekolah Dasar Di Kecamatan Padang Utara dan Nanggalo Kota Padang. Jurnal Ikraith Humanihora, (2),2, 1-8,: https://journals.upiyai.ac.id/index.php/ikraithhumaniora/article/view/109

Rahayu, S. Harjono, A,. \& Gunada, I.W. 2019 Pelatihan Penggunaan KIT IPA Bagi Guru dan Siswa SMP N 1 Sakra Lotim. Jurnal Pengabdian, Masyarakat Sains Indonesia, (1),1,11-13.: http://jpfis.unram.ac.id/index.php/jpmsi/arti cle/view/4.

Wiyatmo, Y. dkk. 2018. Pelatihan Penggunaan Kit Listrik Magnet SEQIP Bagi Guru-Guru IPA SD di Kabupaten Bantu. Jurnal Pengabdian Masyarakat MIPA dan Pendidikan MIPA, (2), 1, 48-55.: https://journal.uny.ac.id/index.php/jpmmp/ article/view/18723. 